\title{
GROWTH OF THE THREATENED YELLOW CATFISH HORABAGRUS BRACHYSOMA GÜNTHER, 1864 FED WITH DIFFERENT DIETS
}

\author{
Jasmine Hakkim ${ }^{1}$ and G. Prasad ${ }^{2}$ \\ 1,2 Department of Zoology, University of Kerala, Kariavattom, Thiruvananthapuram, Kerala 695581, India \\ Email:2 probios2003@yahoo.co.in (corresponding author)
}

\begin{abstract}
Growth of the threatened Yellow or Günther's Catfish, Horabagrus brachysoma was studied by using three types of feeds, viz., fish muscles, earthworms and pelleted feed. The control fishes fed with pelleted feed recorded the highest growth rate followed by the fish muscles. The survival rate of the fishes was $100 \%$ as no mortality was observed during the experiment.
\end{abstract}

\section{KeYWORDS}

Yellow Catfish, Horabagrus brachysoma, conservation, nutrition, growth.

The Yellow or Günther's Catfish, Horabagrus brachysoma Günther (1864), belonging to the family Bagridae, is endemic to the rivers and estuaries of the states of Kerala and Karnataka in southern India. $H$. brachysoma have been receiving considerable focus from researchers and ornamental fish hobbyists. The fish is much relished as food and has a ready market demand in Kerala. The vibrant yellow colour of the fish also makes it a potential ornamental species with high demand in Southeast Asian continental markets. (Beevi \& Ramachandran, 2002; Ramachandran, 2002). Due to the rapid decrease in populations of this species in the wild, the fish has been listed as Endangered in India (Molur \& Walker, 1998). In addition, this catfish is considered to be a potential cultivable species because of its high consumer demand in local markets. The commercial significance of $H$. brachysoma as a much relished food fish and an ornamental species has made it an excellent candidate for commercial aquaculture (Sreeraj, 2005). The National Bureau of Fish Genetic Resources (NBFGR) identified this species as a prioritized one for aquaculture, for repopulation of endemic food / sport fish and for river ranching of endangered, endemic species for conservation. Considering the wide consumer demand, the commercial importance and the declining stocks in the wild, it is evident that by popularizing the culture practice of $H$. brachysoma, especially in the small scale rural farming systems could improve the socio-economic status of the community by augmenting their income and also contribute to the efficient conservation of this endangered and endemic species. However, in order to take up such a venture, detailed information on the nutritional needs of this species is inevitable. Hence an attempt has been made to study the utilization of some natural diets and their effects on the growth and survival of this endangered fish.

\section{Methodology}

Healthy juveniles of the Yellow Catfish, H. brachysoma were procured from the Pampa river and were transported live in oxygen-filled bags to the laboratory. The juveniles were maintained in glass tanks for a week for acclimatization. The feeding experiments were performed in triplicates for a period of 60 days in glass tanks of 101 capacity. Prior to the initiation of the experiment, aquarium tanks were cleaned thoroughly and filled with pond water. Each tank was stocked with two juveniles of $H$. brachysoma. No feed was given on the day prior to the actual start of the experiment to facilitate complete evacuation of food from the gut. The average initial weights of the fishes were noted with an electronic balance. Three types of feeds were used for the study: (1) fish muscles (Stolephorous spp.), obtained from a local fish market; (2) common earthworms (Pheretima spp.), collected from wet fields; and (3) commercial pelleted shrimp feeds (manufactured by Higashimaru Feed India Limited, Alappuzha, Kerala). The fish muscles and earthworms were thoroughly cleaned, weighed and stored in deep freezers. The experimental fish were fed daily, at 5\% of their average initial body weights, where the feed was split into two rations, one to be fed in the morning and the latter in the evening. The first set of experimental fishes were fed with minced fish flesh, the second set with chopped earthworms and the third set were kept as control, which were supplied with pelleted feed. The feeds were provided in a petri-dish placed at the bottom of the tanks. The feed intake was carefully monitored. Care was taken to minimize disturbance to the animal while feeding. The $\mathrm{pH}$ and temperature of the water in the tanks were recorded with the help of a digital $\mathrm{pH}$ meter and thermometer, respectively. The water in the rearing tanks was changed once in three days to remove the toxicants generated if any. The excreta and unfed feed were removed by siphoning daily before the next feed. On termination of the experiment, the fishes were collected and their weights were recorded.

The proximate composition of three feeds were determined following the methods suggested by AOAC (1990). After 60 days of growth period, the increment in the weight of the juvenile was subjected to determine the Growth Rate (GR), Specific Growth Rate (SGR), Food Conversion Ratio (FCR), Food Conversion Efficiency (FCE) and Protein Efficiency Ratio (PER). The data were subjected to two way ANOVA and $t$-test to test the differences if any.

\section{Growth Rate (GR)}

The growth rate of the fish expressed as percentage was calculated as follows:

$$
\begin{array}{ll}
\text { Growth rate }= & \text { Weight gain }(\mathrm{g}) \times 100 \\
\text { - } & \text { Initial weight }
\end{array}
$$

Manuscript 1358; Received 13 May 2005: Revised received 30 June 2005. Finally accepted 20 Oc Zoo Outreach Organisation; www.zoosprint.org 


\section{Specific Growth Rate (SGR)}

The specific growth rate were calculated as per Pillai and Dill (1979).

Specific Growth Rate $=\frac{\log _{\mathrm{e}} \mathrm{W} 2-\log _{\mathrm{e}} \mathrm{W} 1 \times 100}{\mathrm{-} \text { t2-t1 }}$

where, $\mathrm{W} 2=$ final weight, $\mathrm{W} 1=$ initial weight, $\mathrm{t} 2-\mathrm{t} 1=60($ period in days)

\section{Food Conversion Ratio (FCR)}

Food Conversion Ratio is a parameter used to determine the efficiency of feeds for providing the necessary energy for growth. FCR is also known as utilization efficiency. The feed utilization by fish was calculated as:

Food intake (dry wt in g)

Food Conversion Ratio $=$----------------

\section{Food Conversion Efficiency (FCE)}

The Food Conversion Efficiency was calculated as Weight gain $(\mathrm{g}) \times 100$

$\begin{aligned} \text { Food Conversion Efficiency }= & -------------- \\ & \text { Food intake }(\mathrm{g})\end{aligned}$

\section{Protein Efficiency Ratio (PER)}

The Protein Efficiency Ratio was calculated as: Wet weight gain $(\mathrm{g}) \times 100$

Protein Efficiency Ratio = --------------------------------Protein intake $(\mathrm{g})$

\section{Results AND Discussion}

The average daily water temperature ranged from $25^{\circ} \mathrm{C}-28^{\circ} \mathrm{C}$ and $\mathrm{pH}$ from 6.5-7.0 and these two water quality parameters did not show significant variation during the course of the experiment. The survival rate of the fishes were $100 \%$ as no mortality was observed during the experiment. The results are presented in Table 1. The observations showed that the growth was higher for fishes fed with pelleted feed followed by fishes fed with fish muscles. The growth of the fishes provided with earthworms was comparatively low. Table 1 indicated that the control fish fed with pelleted feed exhibited superior growth. Analysis of Variance (ANOVA) and $t$-test showed that this growth is significantly higher than the growth exhibited by the earthworm diet but not significantly different from that fed with fish muscles. From Table 1 it is evident that SGR was higher in fishes fed with pelleted feed followed by fish fed with fish muscles. The lowest SGR was reported for fishes fed with earthworms. The lowest FCR was reported for the control feed (4.38) followed by fish muscles (4.63). The highest FCR was noted for fishes fed with earthworms. The highest FCE and PER was reported by fishes fed with control feed and the lowest FCE and PER values were recorded by fishes fed with earthworms. The maximum protein content was reported by the fish muscles $(53.4 \%)$ followed by earthworms $(52.6 \%)$. The protein content of control feed was $39 \%$.
Table 1.

\begin{tabular}{llll}
\hline Parameters & Trash fish & $\begin{array}{l}\text { Diets } \\
\text { Earthworms }\end{array}$ & Pelleted feed \\
\hline Mean \pm SD & $12.1 \pm 0.249$ & $6.5 \pm 0.374$ & $13.6 \pm 0.294$ \\
Growth rate (\%) & 55.00 & 32.50 & 65.38 \\
Specific growth rate (\%) & 0.72 & 0.47 & 0.84 \\
Food conversion ratio (gm) & 4.63 & 4.984 & 4.58 \\
Food conversion & 21.57 & 20.06 & 21.79 \\
efficiency (gm) & & & \\
Protein efficiency ratio (gm) & 22.65 & 12.35 & 38.52 \\
& & Proximate composition \\
Protein (\%) & 53.4 & 52.6 & 39.0 \\
Fat (\%) & 2.7 & 1.8 & 12.5 \\
Fibre (\%) & 11.6 & 8.8 & 12.2 \\
Ash (\%) & 3.4 & 2.2 & 4.8 \\
\hline
\end{tabular}

The results of the present experiment clearly reveal that $H$. brachysoma can be easily reared in controlled conditions with locally available feed stuffs or prepared feeds. This species can be well adapted to controlled conditions and accept feeds which are of animal origin. The survival rate was 100 percent in the experiment which shows the hardy nature of this species as like any other catfish species. The higher growth rate of the control fishes may be because of the better amino acid balance of the pelleted feed by virtue of more than one protein source as reported by Alava and Lin (1983). The SGR and Growth Rate for the fishes fed with fish muscles are slightly lower than those of pelleted feed but these values for the fishes fed with earthworms is significantly lower. This clearly proves that this catfish can be reared in confined conditions by feeding with trash fishes, but the worms will provide only poor results even though this feed is readily accepted by H. brachysoma. This is mainly due to the difference in the amino acid profile of the two feeds. The marine pelagic fish Stolephorus spp. could have provided better essential amino acid profile than that of the earthworms. This clearly shows that protein of marine origin is better utilized and converted into body protein by $H$. brachysoma than the other type of proteins. The results clearly depicts that all the feeds were accepted by the catfish juveniles and the superior growth of the control fishes fed with dry pellets may be attributed to the efficiency of the commercial shrimp pelleted feed. The feed was formulated and prepared in a way to provide the shrimp with all energy and nutritional requirements. Similar results were obtained in the channel catfish, Ictalurus punctatus fed on $5 \%$ of the trout pellets $(46 \%$ protein) (Gracia et al., 2002).

The results also shows that the fish flesh is not far behind in giving the best results as the fish muscles fed group recorded a $55 \%$ growth rate. Moreover the $t$-test analysis revealed no significant differences in the average growth between the groups fed on fish flesh and pelleted feed. On the other hand the fishes fed with earthworms showed inferior growth when compared to the other treatments. Even though the commercial dry pellets used in the experiment aid in best results, there are certain limitations for its usage. Owing to the high market value of the pelleted feeds which ranges from Rs. 60 to $70 / \mathrm{kg}$ are not affordable by the common small-scale farmers. Therefore it is not advisable to use these pellets for farming of the $H$. 
brachysoma. It is well known that, in aquaculture, as in any other form of husbandry both nutrition and feed cost have to be taken into account. Feed cost is considered to be the highest operational cost in both intensive and semi-intensive aquaculture systems, and therefore special consideration need to be given to this aspect in diet formulation (De Silva \& Anderson, 1995).

On comparison with the pelleted feed, fish muscles are economical, cost-effective and go hand in hand in providing efficient growth for $H$. brachysoma. Most studies have emphasized comparisons of trash fish based diets with mixed feeds by assessing their quality and cost effectiveness (Jantrarotai \& Jantrarotaj, 1993). Thongutai (1969) (cited by Jantrarotai \& Jantrarotaj, 1993) reported superior growth of catfish Clarias batrachus fed 9:1 trash fish: rice bran diet to those receiving pelleted feed, in which fish meal and soya bean were included as protein sources. Srisuwantach et al. (1981) reported similar findings when they compared the effects of trash fish and pelleted feed in catfish grow-out operations. Sambhu (2004) through his experiments on the catfish, Clarias gariepinus, reported that butcher waste and fish waste fed fishes showed higher growth rate than kitchen waste and ware house waste fed fishes. This shows that the catfishes can very efficiently assimilate a wide variety of protein. Keeping in phase with the results of above workers, the yellow catfish can be fed on trash fish and cultured effectively thereby conserving them along with that they could be used to recycle different bio-wastes to fish protein, in a cost-effective way, when compared with that of the pelleted feeds.

\section{Conclusion}

From the observations, it may be concluded that even though the catfish juveniles fed on the commercially prepared shrimp pelleted feed exhibited superior growth, due to the 'uneconomic' nature of this feed, locally generated animal waste like the trash fish may be utilized for the rearing of $H$. brachysoma. Considering the wide consumer demand, the commercial importance and the declining stocks in the wild, it is evident that by utilizing the 'economic diets', like the fish muscles, the culture practices of $H$. brachysoma can be popularized in the small-scale rural farming systems which could improve the socioeconomic status of the community by augmenting their income and also contribute to the efficient conservation of this endangered and endemic species.

\section{REFERENCES}

Alava, V.R. and C. Lim (1983). The qualitative dietary protein requirements of Penaeus monodon juveniles in controlled environment. Aquaculture 30: 53-61.

AOAC, (1990). Official Methods of Analysis, $15^{\text {th }}$ Edn., Association of Official Analytical Chemists, Arlington, V.A., 1298pp.

Beevi, J. and A. Ramachandran (2002). Ornamental fish resources of Muvatupuzha River System, pp. 400-415. In: Riverine and Reservoir Fisheries of India. Boopendranath, M.R, B. Meenakumari, J. Joseph, T.V. Sankar, P. Pravin and L. Edwin (Eds.). CIFT and SOFT (1), Kochi, India.

Molur, S. and S. Walker (Eds.) (1998). Report of the Workshop "Conservation Assessment and Management Plan for Freshwater Fishes of India", Zoo Outreach Organization, CBSG, India, Coimbatore, India, $156 \mathrm{pp}$.

De Silva S.S. and T.A. Anderson (1995). Fish Nutrition in Aquaculture. Chapman and Hall, London, New York, Madras, 287pp.

Gracia, L.V., S.I Garcia and F. Castello-Orvay (2002). Effect of daily food intake rate and different artificial feeds on the growth and feeding parameters of Channel Catfish, Ictalurus punctatus. Review of Investigations 23(2): 149-153.

Jantrarotai, W. and P. Jantrarotai (1993). On farm feed preparation and feeding strategies for catfish and snakehead, pp.109-119. In: New, M.B., A.G.J. Tacon and I. Csavas (eds.) Farm made Aquafeeds. Proceedings of the FAO/AADCP Regional Expert Consultation on Farm made Aquafeeds, Bangkok, Thailand.

Pillai, T.V.R. and W.A. Dill (1979). Advances in Aquaculture. Fishing News Books, Farnham, 985pp.

Ramachandran, A. (2002). Freshwater indigenous ornamental fish resources of Kerala and their prospects for international marketing, pp. 109-135. In: Boopendranath, M.R., B. Meenakumari, J. Joseph, T.V. Sankar, P. Pravin and L. Edwin (Eds.) Riverine and Reservoir Fisheries of India. Central Institute of Fisheries Technology and Society of Fisheries Technologists, India.

Sambhu, C. (2002). African Catfish, Clarias gariepinus (Burchell, 1822): An ideal candidate for bio-waste management. Indian Journal of Experimental Biology 42: 1226-1229.

Sreeraj, N. (2005). Some aspects of the fishery biology and conservation of the endangered Yellow Catfish, Horabagrus brachysoma (Gunther, 1864) from the Vembanad lake, Kerala, India. M.Sc Dissertation, Department of Aquaculture, St. Alberts College, Kochi 682018.

Srisuwantach, V., R. Soungchomphan and P. Sitasit (1981). Comparison of the effects of trash fish and pelleted diets in Clarias grow out operations. Report on Programme for the Development of Pond Management Techniques and Disease Control (DOF UNDP/FAO THA/ 75/012), Thailand, $21 \mathrm{pp}$.

\section{ACKNOWLEDGEMENT}

The authors are grateful to the Kerala State Council for Science, Technology and Environment for the financial assistance extended for the project on endangered catfishes.

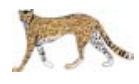

\section{M.Sc. in Wildlife Biology \& Conservation}

The course is offered once in two years. Admission is now open for the course beginning in July 2006. Indian nationals, who have completed their graduation in any subject, or are in the final year of graduation with an aggregate of at least $50 \%$ in core subjects, are eligible to apply. The upper age limit for candidates is 35 years as on July $1^{\text {st }} 2006$.

Applications should be submitted in the prescribed format (available at www.wcsindia.org) by January 13, 2006. Electronic submission of application is not permitted.

For more information contact Dr. Ajith Kumar

Course Director (M.Sc. Wildlife Biology \& Conservation) National Centre for Biological Sciences

Post Box 6501, G.K.V.K. Campus Hebbal, Bangalore 560065

Email: ajith@ncbs.res.in 